Journal of Al-Azhar University Engineering Sector

Vol.15, No. 57, October, 2020, 1112-1124

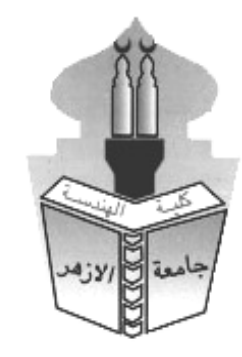

\title{
STUDY OF BENTONITE USAGE IN ENVIRONMENTALLY FRIENDLY CONCRETE
}

\author{
Soheir Abdelfatah Ghonaim* ${ }^{1}$ and Rana AbdelMotaleb Morsy ${ }^{2}$ \\ ${ }^{1 *}$ Department of Chemical Engineering, Faculty of Engineering and Technology, Badr University \\ Cairo, Egypt. \\ ${ }^{2}$ Department of Civil Engineering, Housing and Building Research Center, Giza, Egypt. \\ *Corresponding Author E-mail: sohair_abdelfatah@yahoo.com
}

\begin{abstract}
:
Production of cement generates a huge amount of carbon dioxide emissions into the environment, utilization of pozzolanic materials in concrete is a better solution for this environmental problem. Several studies are conducted for using of pozzolanic materials such as fly ash, ground granular blast furnace slag, and silica fume as a pozzolanic material in concrete. A few studies were available on using bentonite in concrete. Bentonite is mainly clay contains rich amount of silicain which obeys the pozzolanic properties. The objective of present study is to find out the effectiveness of using bentonite and waste rubber crumb in the design mix of concrete. An experimental investigation is performed on concrete mixtures to study the effect of using bentonite as a partial replacement of cement and conducting an environmentally friendly concrete using crumb rubber in the concrete mixtures as a partial replacement of fine aggregates. Cement is partially replaced by volume $(2 \%, 5 \%, 10 \%, 15 \%, 20 \%)$ with Bentonite and fine aggregate is partially replaced $(5 \%, 20 \%, 25 \%, 30 \%, 40 \%)$ with crumb rubber. Slump tests were conducted to evaluate the workability of fresh concrete. Compressive strength of cubes at 7 days and 28 days, splitting strength and abrasion strength at 28 days are studied and compared with conventional concrete. A part of research work addresses the effect of using bentonite and waste rubber crumb on durability of concrete. For this purpose, specimens were submerged in solution containing 50 $\mathrm{g} / 1$ of $\mathrm{NaOH}$ and $\mathrm{H}_{2} \mathrm{SO}_{4}$. Based on the test results, the ideal percentage of mix which shows maximum compressive strength is identified. The results showed that the compressive strength of the concrete was generally increases when bentonite replaced a part of the cement and decreases with the replacement of fine aggregates by the waste crumb rubber. Although the using of bentonite and crumb rubber decreases the compressive strength. The optimal mixture from the laboratory experimental investigation is 5\% reduction of cement content and $20 \%$ of fine aggregates replacement that exhibited a compressive strength of $30 \mathrm{MPa}$ at 28 days. The test results substantiate the feasibility to develop environmentally friendly concrete using bentonite and crumb rubber in the concrete mixtures.
\end{abstract}

KEYWORDS: Bentonite, Rubber crumb, Compression strength, Durability, Concrete. 

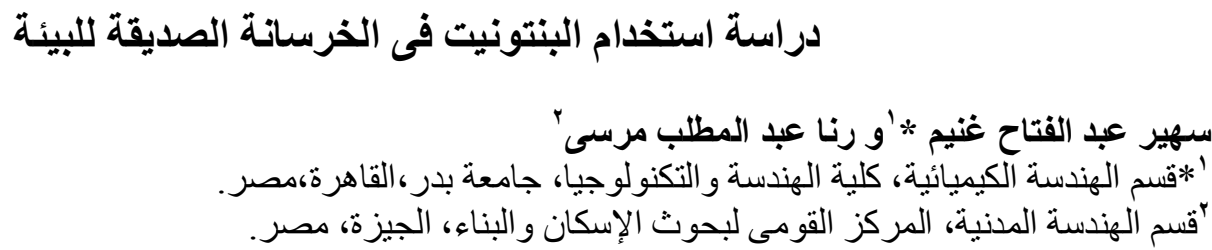

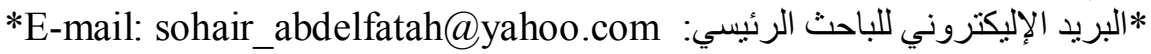

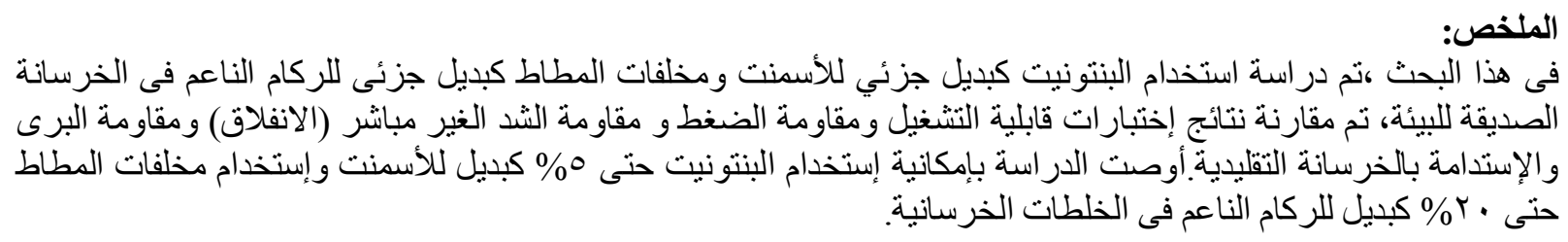

الكلمات المفتاحية: البنتونيت، مخلفات المطاط، مقاومة الضغط، الإستدامة، الخرسانة.

\section{INTRODUCTION}

Bentonite has a major application such as drilling fluids, absorbents, adhesives, bleaching earths (Alkaya et al., 2011). In 2002 the research work was initiated for using bentonite as substitute material to cement in concrete and plenty of investigations were carried out by researchers reporting some facts related to bentonite utilization based on the experimental results. The effect of bentonite, colemanite ore waste, coal fly ash and coal bottom ash on the properties of cement and concrete has been investigated through several tests. The result showed that setting time of the cements was generally accelerated when bentonite replaced a part of the cement. Bentonite showed a significant retarding effect when used in combination with colemanite ore waste in Portland cement at lower replacement level and showed an accelerating effect at higher replacement level. Although the inclusion of bentonite at replacement levels of 5-10\% resulted in an increase in compressive strength at early ages, it decreased the compressive strength when used in combination with other materials (Targan et al.,2002).

(Mirza et al., 2009) performed tests by varying bentonite (0-50\%) at room temperature and heated at $1500 \mathrm{C}$ for 3 hours and the results showed that $20 \%$ of bentonite substituted concrete mixes and heated at $1500 \mathrm{C}$ for 3 hours exhibit better compressive strength at 28 days curing among all and reported that no change observed in flexure strength by heated bentonite over raw bentonite, decrease in flexure strength was reported by using of bentonite to concrete. (Khushnood et al., 2014) reported heated bentonite blended concrete mixes shown higher compressive strength than raw bentonite .

(Memon et al., 2012) examined up to $21 \%$ bentonite substitution, reported that lower compressive strength exhibits at the age of 3,7day, and a better result shown at 28, 56 days after curing and bentonite substitution, and reported that decrease in water absorption by increasing percentage of bentonite blending. Bentonite substitution achieve the low-cost concrete and improve the durability of the system by testing bentonite blended concrete against to hydrochloric acid and Sulfuric acid. he recommended utilization of super plasticizer needed to enhance workability. (Junaid Akabr, 2013) investigates at 20\% bentonite substitution, poor compressive strength results were reported when comparing with control mix but on the other hand, it showed very good resistance to sulfate attack. (Karthikeyan et al., 2015) reported that $30 \%$ substitution of bentonite results maximum split tensile strength to concrete.

Experimental investigates has been performed on bentonite-fly ash concrete mixes, reported that the concrete contains equal combination $(50-50 \%)$ of bentonite and fly ash exhibits better results at the age of 90 days (Shabab et al.,2016). In 2017 experiments are performed as per standard procedure IS 5816, results that lower split tensile strength was observed in bentonite blended mixes (Reddy G et al., 2017). (Divyana, 2015) laboratory results indicate a better splitting 
tensil" "e strength by $20 \%$ bentonite replacement. (Chandrakanth et al., 2016) showed that $5 \%$ bentonite addition improves flexure strength of concrete. (Sreenivasa et al., 2017) reported that $15 \%$ bentonite blended concrete shown great resistance against hydrochloric acid.

Bentonite is used in self-healing cracks of cement paste associated with ground granulated blast furnace slag. The self-healing properties were evaluated with four parameters: crack width on the surface, crack depth, tensile strength recovery, and flexural recovery. The results show that bentonite improves the healing properties, in terms of surface crack width and crack depth (Ekaputri et al., 2018). A laboratory testing indicates the use of bentonite within the concrete can provide one of the best solutions to decrease the expansion due to alkali silica reaction through the protection of the concrete skeleton and provide a positive impact on the durability of the concrete (Tahiri et al.,2018).

The research significance of this work is to offer an attractive low-cost environmentally friendly concrete. The use of bentonite supplementary cementitious materials as a partial replacement by volume of cement content has many benefits such as decreasing the usage of natural resources, wastes consumption, avoiding the environmental pollution by $\mathrm{CO}_{2}$ and economizing energy. An experimental investigation is performed to study the effect of using bentonite as a partial replacement of cement on concrete and using crumb rubber as a partial replacement of fine aggregates. The experimental investigations performed on several concrete mixtures and testing includes slump test, compressive strength; tensile strength; abrasion testing and ultrasonic pulse velocity testing.

\section{MATERIALS}

The main objective was to produce a concrete mix that can achieve a compressive strength of $30 \mathrm{MPa} .16$ mixes are designed with different replacement percentages of cement with bentonite and crumb rubber and with constant coarse aggregate, fine aggregate and w/c ratio.

\subsection{Bentonite}

Bentonite is an absorbent aluminum phyllosilicate, impure clay consisting mostly of montmorillonite generated from the alteration of volcanic ash as in figure (1). Bentonite is available in powder and solution form contains different minerals in addition to montmorillonite, these minerals may include quartz, calcite, feldspar and gypsum. It presents strong colloidal properties when comes in contact with water, its volume also increases several times, creating gelatinous and viscous fluid. The chemical composition of bentonite allows its usage as a partial replacement for cement. XRF and XRD tests are performed on the used bentonite, and the results are shown in table (1) and figure (2). The XRD of bentonite shows that the main phases are kaolinite $\left(\mathrm{Al}_{2} \mathrm{Si}_{2} \mathrm{O}_{5}(\mathrm{OH})_{4}\right)$, Albite , Calcite $\left(\mathrm{CaCO}_{3}\right)$ and quartz $\left(\mathrm{SiO}_{2}\right)$.

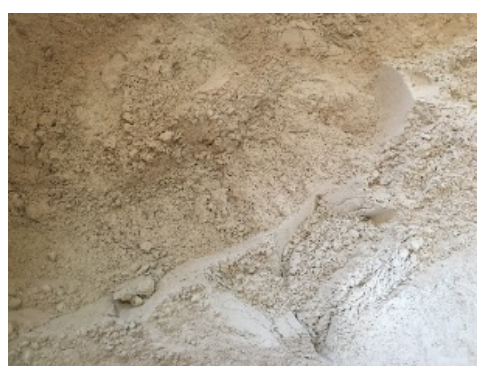

Figure, (1) volcanic ash, bentonite

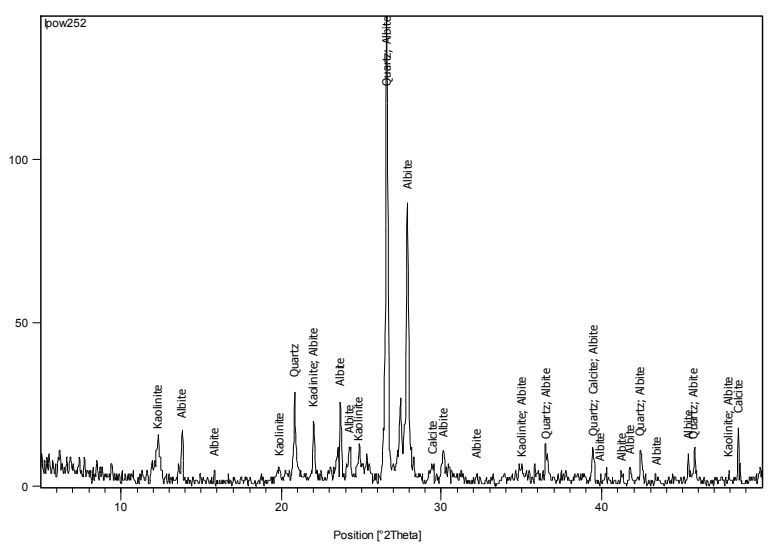

Figure, (2) XRD Pattern for Bentonite 
Table (1), chemical analysis of bentonite -XRF

\begin{tabular}{|c|c|}
\hline Compound & Amount \\
\hline $\mathrm{Si} \mathrm{O}_{2}$ & 65.00 \\
\hline $\mathrm{Al}_{2} \mathrm{O}_{3}$ & 18.50 \\
\hline $\mathrm{Fe}_{2} \mathrm{O}_{3}$ & 1.43 \\
\hline $\mathrm{Na}_{2} \mathrm{O}$ & 3.20 \\
\hline $\mathrm{PdO}$ & 2.41 \\
\hline $\mathrm{MgO}$ & 1.73 \\
\hline $\mathrm{CaO}$ & 1.00 \\
\hline $\mathrm{K}_{2} \mathrm{O}$ & 0.95 \\
\hline $\mathrm{Ti} \mathrm{O}_{2}$ & 0.27 \\
\hline $\mathrm{SO}_{3}$ & 0.19 \\
\hline $\mathrm{P}_{2} \mathrm{O}_{5}$ & 0.13 \\
\hline $\mathrm{MnO}_{2}$ & 0.03 \\
\hline $\mathrm{Zr} \mathrm{O}_{2}$ & 0.01 \\
\hline $\mathrm{Co}_{3} \mathrm{O}_{4}$ & 0.01 \\
\hline $\mathrm{ZnO}^{-}$ & 0.01 \\
\hline $\mathrm{Cl}^{-}$ & 0.09 \\
\hline $\mathrm{L} . O . I^{\mathrm{Total}}$ & 4.98 \\
\hline & 99.94 \\
\hline
\end{tabular}

\subsection{Cement}

The Ordinary Portland Cement was used in this study.

\subsection{Aggregates}

The coarse and fine aggregates were used in the concrete mix. The selected aggregate size for the coarse aggregate was $5 \mathrm{~mm}, 10 \mathrm{~mm}$ and $20 \mathrm{~mm}$. The aggregate properties that have been used in the experimental investigation are given in Table (2).

Table (2), Concrete Components properties

\begin{tabular}{|c|c|c|c|}
\hline Description & Cement & Coarse aggregate & Fine aggregate \\
\hline Fineness Modulus & 1.78 & - & 3.66 \\
\hline Specific Gravity $\left(\mathrm{g} / \mathrm{cm}^{3}\right)$ & 3.15 & 2.61 & 2.45 \\
\hline Water Absorption $(\%)$ & 0.88 & 0.68 & 2.04 \\
\hline
\end{tabular}

\subsection{Crumb rubber}

The size of crumb rubber that used in the experimental investigation is chipped tire with the size of $20 \mu \mathrm{m}$ is generated by mechanical grinding at ambient temperature. The reduction of rubber size to about $20 \mu \mathrm{m}$ comparable to sand particles as shown in figure (3). Crumb rubber is added to the concrete mixtures as a waste disposal with different percentages $5 \%, 20 \%, 25 \%, 30 \%, 40 \%$ from the fine aggregate. The physical properties of the crumb rubber relevant for this study are particle shape and size. Figure (4) shows the sieve analysis for both the crumb rubber particles and the fine aggregates (sand) used. 


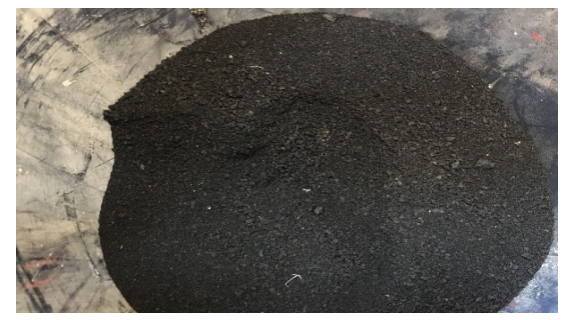

Figure (3), Crumb rubber used for the concrete mixtures

\section{MIX DESIGN}

In this study, 16 series of concrete mixtures classified into three main groups is as shown below in Table (3). Group A mixtures are conducted by adding bentonite with various contents of the total cement volume as a partial replacement of cement, group B are mixed with different content of crumb rubber as a partial replacement of fine aggregates and group $\mathrm{C}$ are the mixtures for replacement of cement and fine aggregates. The produced concrete series are coded according to the ratio of reduction percent in the concrete mix as given in the Table (4).

Table (3), Concrete mixtures coding and descriptions

\begin{tabular}{|c|c|c|}
\hline & Mixture code & Description \\
\hline \multirow{5}{*}{ 岂 } & Mix-B1 & mixture with $2 \%$ cement replacement \\
\hline & Mix-B2 & mixture with $5 \%$ cement replacement \\
\hline & Mix-B3 & mixture with $10 \%$ cement replacement \\
\hline & Mix-B4 & mixture with $15 \%$ cement replacement \\
\hline & Mix-B5 & mixture with $20 \%$ cement replacement \\
\hline \multirow{5}{*}{ ڤొ } & Mix-CR1 & mixture with 5\% sand replacement \\
\hline & Mix-CR2 & mixture with $20 \%$ sand replacement \\
\hline & Mix-CR3 & mixture with $25 \%$ sand replacement \\
\hline & Mix-CR4 & mixture with $30 \%$ sand replacement \\
\hline & Mix-CR5 & mixture with $40 \%$ sand replacement \\
\hline \multirow{6}{*}{ Ů } & Mix-1 & Control mix with no replacement \\
\hline & Mix-2 & mixture with $2 \%$ cement replacement and 5\% sand replacement \\
\hline & Mix-3 & mixture with $5 \%$ cement replacement and $20 \%$ sand replacement \\
\hline & Mix-4 & mixture with $10 \%$ cement replacement and $25 \%$ sand replacement \\
\hline & Mix-5 & mixture with $15 \%$ cement replacement and $30 \%$ sand replacement \\
\hline & Mix-6 & mixture with $20 \%$ cement replacement and $40 \%$ sand replacement \\
\hline
\end{tabular}


STUDY OF BENTONITE USAGE IN ENVIRONMENTALLY FRIENDLY CONCRETE

Table (4), The design mix ratios of the concrete types for $1 \mathbf{m}^{3}$

\begin{tabular}{|c|c|c|c|c|c|c|c|c|}
\hline & \multirow{3}{*}{ Mixture } & \multicolumn{7}{|c|}{ Weight (Kg) } \\
\hline & & \multirow{2}{*}{ Cement } & \multirow{2}{*}{ Bentonite } & \multirow{2}{*}{ Rubber } & \multirow{2}{*}{ Sand } & \multicolumn{3}{|c|}{ Gravel } \\
\hline & & & & & & $(20 \mathrm{~mm})$ & $(10 \mathrm{~mm})$ & $(5 \mathrm{~mm})$ \\
\hline \multirow{5}{*}{ 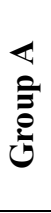 } & Mix-B1 & 431 & 6.7 & 0 & 660 & 440 & 290 & 440 \\
\hline & Mix-B2 & 420 & 16.8 & 0 & 660 & 440 & 290 & 440 \\
\hline & Mix-B3 & 397 & 33.5 & 0 & 660 & 440 & 290 & 440 \\
\hline & Mix-B4 & 375 & 50.3 & 0 & 660 & 440 & 290 & 440 \\
\hline & Mix-B5 & 352 & 67.0 & 0 & 660 & 440 & 290 & 440 \\
\hline \multirow{5}{*}{ ڤ̊ } & Mix-CR1 & 440 & 0 & 15 & 627 & 440 & 290 & 440 \\
\hline & Mix-CR2 & 440 & 0 & 61 & 528 & 440 & 290 & 440 \\
\hline & Mix-CR3 & 440 & 0 & 76 & 495 & 440 & 290 & 440 \\
\hline & Mix-CR4 & 440 & 0 & 91 & 462 & 440 & 290 & 440 \\
\hline & Mix-CR5 & 440 & 0 & 121 & 396 & 440 & 290 & 440 \\
\hline \multirow{6}{*}{ Ů } & Mix-1 & 440 & 0 & 0 & 660 & 440 & 290 & 440 \\
\hline & Mix-2 & 431 & 6.7 & 15 & 627 & 440 & 290 & 440 \\
\hline & Mix-3 & 420 & 16.8 & 61 & 528 & 440 & 290 & 440 \\
\hline & Mix-4 & 397 & 33.5 & 76 & 495 & 440 & 290 & 440 \\
\hline & Mix-5 & 375 & 50.3 & 91 & 462 & 440 & 290 & 440 \\
\hline & Mix-6 & 352 & 67.0 & 121 & 396 & 440 & 290 & 440 \\
\hline
\end{tabular}

\section{EXPERIMENTAL INVESTIGATION}

\subsection{Specimen Preparation}

Concrete mixing was done in a laboratory pan mixer and in accordance with ASTM C192/192M06. Slump tests were performed on the mixes to measure consistency as described in ASTM C1611 / C1611M-18 and recorded as per Table (5). The mixes were then prepared and cured according to ASTM C192/192M-06. 150x150x150mm moulds were used for casting the concrete cubes. Three specimens were tested per mix and compacted on a vibrating compactor and the curing method described in the standard was made figure (5).
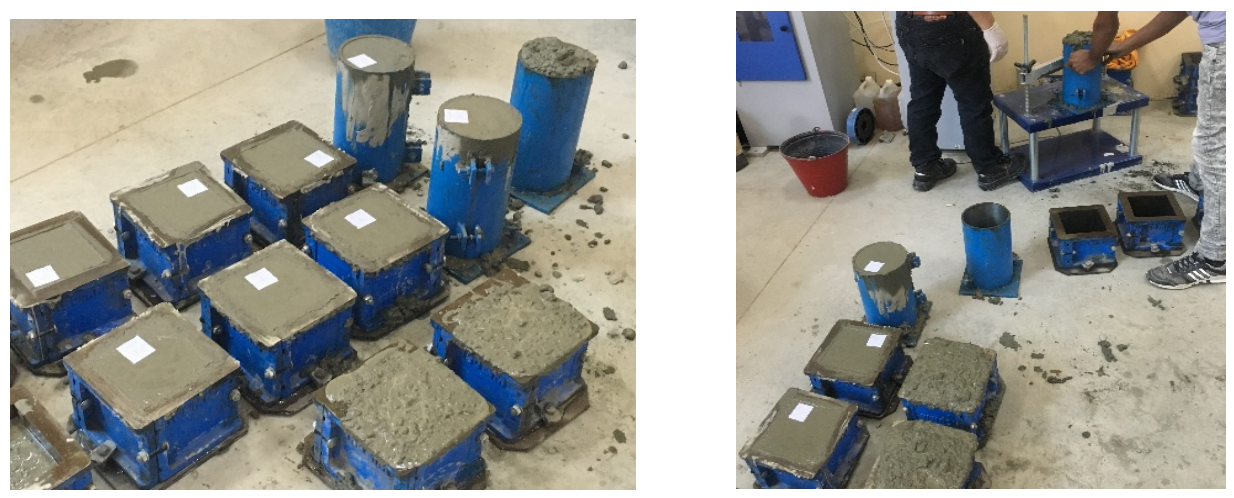

Figure (5), Specimens preparations for the experimental investigation

\subsection{Workability}

Flow values of slumps are reported in table (5) that evidences a noticeable decrease of the slump value from reference mixture Mix-1 because of the amount of bentonite. Increasing the amount of rubber with its smooth surface allows a better mix workability at the same bentonite amount as in figure (6). 

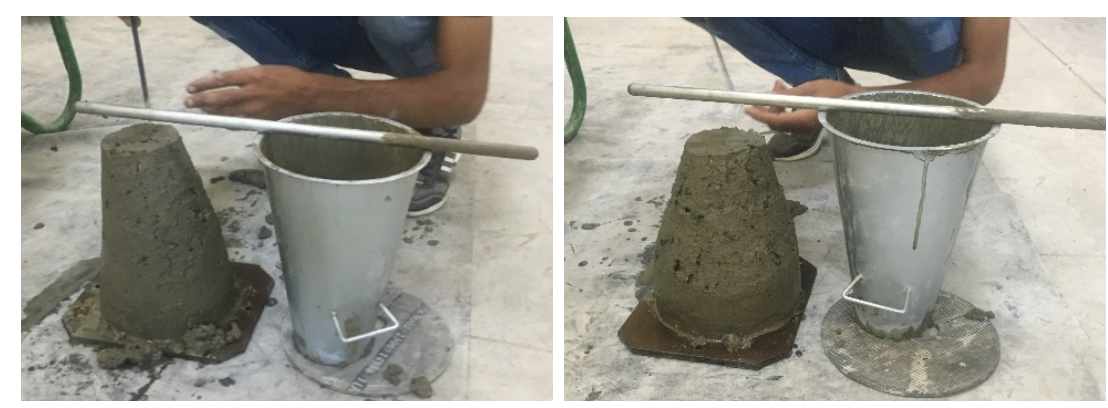

Figure, (6) Slump test

Three mixtures were casted with fixed amount of water content as designed for the reference mixture and the compressive strength has been evaluated and compared to the same mixes but with fixed w/c ratio. The results tabled in table (5) showed that the mixes with fixed $\mathrm{w} / \mathrm{c}$ ratio gives higher compressive strength than with fixed water content as shown in the figure (6).

Table (5), Compressive strength results relative to the water contents

\begin{tabular}{|c|c|c|c|c|c|}
\hline \multirow[t]{2}{*}{ Mixtures } & \multirow{2}{*}{$\begin{array}{l}\text { Water } \\
\text { content }\end{array}$} & \multirow{2}{*}{$\begin{array}{c}\text { Cement } \\
\text { Replacement \% }\end{array}$} & \multirow{2}{*}{$\begin{array}{l}\text { Slump } \\
(\mathrm{mm})\end{array}$} & \multicolumn{2}{|c|}{$\begin{array}{c}\text { Compressive strength } \\
\left(\mathrm{N} / \mathrm{mm}^{2}\right)\end{array}$} \\
\hline & & & & 7 days & 28 days \\
\hline $\operatorname{Mix}(1)$ & \multirow{3}{*}{$\begin{array}{l}\text { Constant } \\
\text { w/c ratio }\end{array}$} & 10 & 70 & 23 & 41 \\
\hline Mix (2) & & 15 & 70 & 22 & 42 \\
\hline Mix (3) & & 20 & 65 & 19 & 38 \\
\hline Mix (1) & \multirow{3}{*}{$\begin{array}{l}\text { Constant } \\
\text { water } \\
\text { content }\end{array}$} & 10 & 115 & 18 & 28 \\
\hline Mix (2) & & 15 & 220 & 13 & 20 \\
\hline Mix (3) & & 20 & 160 & 17 & 23 \\
\hline
\end{tabular}

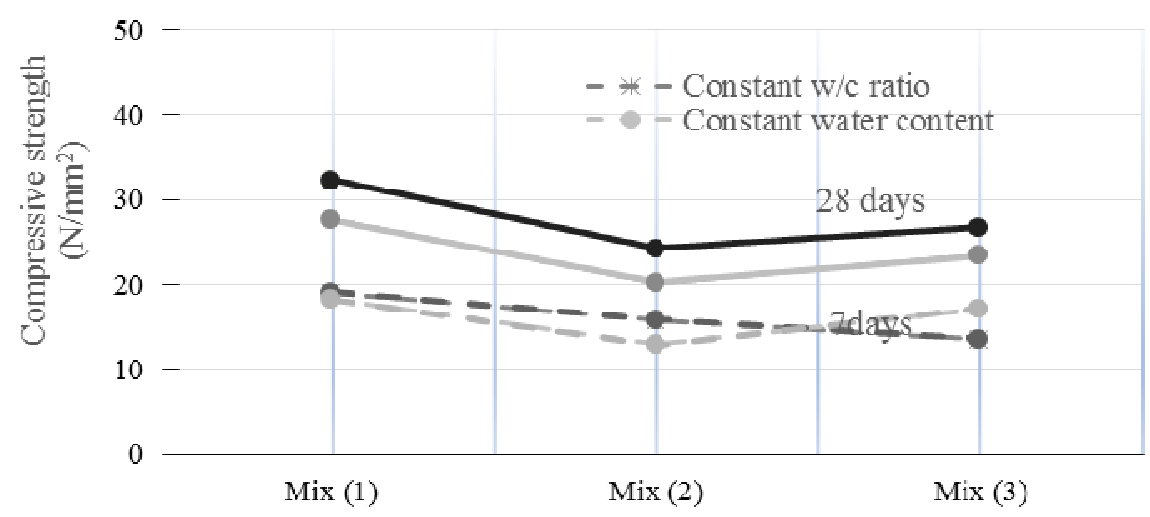

Figure (6), Compressive strength results relative to the water contents at 7 and 28 days

\section{3 compressive strength tests}

Compressive strength tests were conducted according to BS EN 12390-3:2019 as shown in figure (7). The concrete cubes were tested at 7, and 28 days and the results tabled in table (6). Each test batch was prepared for a specific age. 


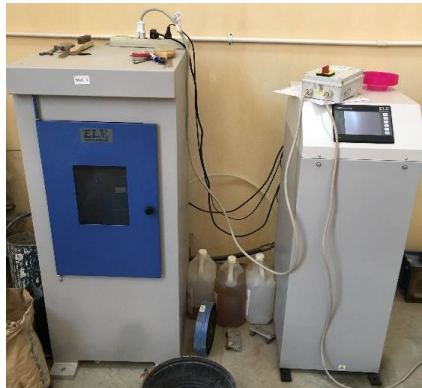

Figure (7), Compressive strength testing machine

Table (6), Compressive strength of the designed mixtures

\begin{tabular}{|c|c|c|c|c|}
\hline & \multirow[t]{2}{*}{ Mixture } & \multirow{2}{*}{$\begin{array}{r}\text { Slump } \\
(\mathrm{mm})\end{array}$} & \multicolumn{2}{|c|}{$\begin{array}{c}\text { Compressive strength } \\
\left(\mathbf{N} / \mathbf{m m}^{2}\right)\end{array}$} \\
\hline & & & 7-days & 28-days \\
\hline \multirow{5}{*}{ 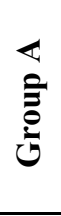 } & Mix-B1 & 78 & 24 & 42 \\
\hline & Mix-B2 & 75 & 23 & 41 \\
\hline & Mix-B3 & 70 & 23 & 41 \\
\hline & Mix-B4 & 70 & 22 & 42 \\
\hline & Mix-B5 & 65 & 19 & 38 \\
\hline \multirow{5}{*}{ 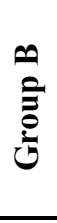 } & Mix-CR1 & 75 & 23 & 38 \\
\hline & Mix-CR2 & 57 & 18 & 30 \\
\hline & Mix-CR3 & 56 & 13 & 21 \\
\hline & Mix-CR4 & 54 & 9 & 16 \\
\hline & Mix-CR5 & 52 & 4 & 8 \\
\hline \multirow{6}{*}{$\underset{0}{0}$} & Mix-1 & 80 & 24 & 40 \\
\hline & Mix-2 & 71 & 23 & 41 \\
\hline & Mix-3 & 60 & 20 & 36 \\
\hline & Mix-4 & 47 & 18 & 33 \\
\hline & Mix-5 & 45 & 16 & 29 \\
\hline & Mix-6 & 40 & 12 & 23 \\
\hline
\end{tabular}

\subsection{Ultrasonic pulse velocity (upv) test}

This test is based on the measurement of the passing time of sound velocity in the material according to ASTM C597-16. The ultrasonic sound device measures how long the sound wave passes through a distance between the two opposing surfaces of the concrete as presented in figure (8). In this study, $150 \times 150 \times 150 \mathrm{~mm}$ cubes concrete specimens were used to obtain UPV value of concrete. UPV values are found on the concrete specimens at the end of the days 28 before the compression strength test given in Table (7).

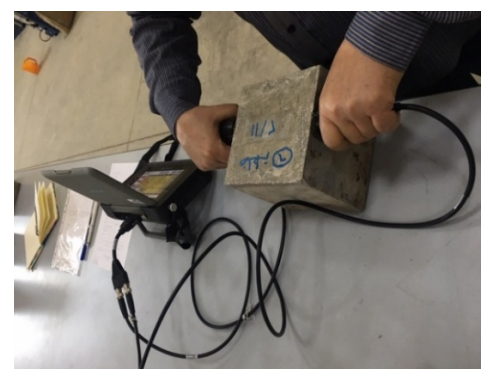

Figure (8), Ultrasonic Pulse Velocity (UPV) test 
STUDY OF BENTONITE USAGE IN ENVIRONMENTALLY FRIENDLY CONCRETE

Table (7), Compressive strength and wave velocity using UPV

\begin{tabular}{|c|c|c|c|c|}
\hline & \multirow[t]{2}{*}{ Mixture } & \multirow{2}{*}{$\begin{array}{l}\text { Velocity } \\
(\mathbf{k m} / \mathbf{s})\end{array}$} & \multicolumn{2}{|c|}{$\begin{array}{c}\text { Compressive strength } \\
\left(\mathrm{N} / \mathbf{m m}^{2}\right)\end{array}$} \\
\hline & & & 7-days & 28-days \\
\hline \multirow{5}{*}{ 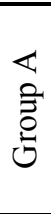 } & Mix-B1 & 4.65 & 23 & 40 \\
\hline & Mix-B2 & 4.67 & 22 & 40 \\
\hline & Mix-B3 & 4.64 & 21 & 41 \\
\hline & Mix-B4 & 4.63 & 19 & 41 \\
\hline & Mix-B5 & 4.52 & 18 & 42 \\
\hline \multirow{5}{*}{$\begin{array}{l}n \\
\text { صి } \\
0 \\
0 \\
0\end{array}$} & Mix-CR1 & 4.56 & 22 & 40 \\
\hline & Mix-CR2 & 4.47 & 17 & 38 \\
\hline & Mix-CR3 & 4.06 & 12 & 30 \\
\hline & Mix-CR4 & 3.98 & 8 & 21 \\
\hline & Mix-CR5 & 3.85 & 4 & 16 \\
\hline \multirow{6}{*}{ 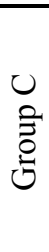 } & Mix-1 & 4.62 & 22 & 40 \\
\hline & Mix-2 & 4.59 & 21 & 40 \\
\hline & Mix-3 & 4.50 & 18 & 36 \\
\hline & Mix-4 & 4.47 & 16 & 33 \\
\hline & Mix-5 & 4.16 & 14 & 29 \\
\hline & Mix-6 & 4.10 & 11 & 23 \\
\hline
\end{tabular}

\section{5 splitting test}

Splitting tensile strength test on concrete cylinder is a method to determine the tensile strength of concrete, the procedure based on the ASTM C496 / C496M-17 Standard Test as shown in figure (9). Splitting strength test results are given in table (8). Splitting tensile strength reduced by $31 \%$ when $25 \%$ (rubber waste) was used and it was the same when a $15 \%$ replacement of cement when compared to conventional concrete. By replacement of sand and cement the splitting strength decreased by $16 \%$ with (mixture with $10 \%$ cement replacement and $25 \%$ sand replacement) and $30 \%$ with (mixture with $20 \%$ cement replacement and $40 \%$ sand replacement).

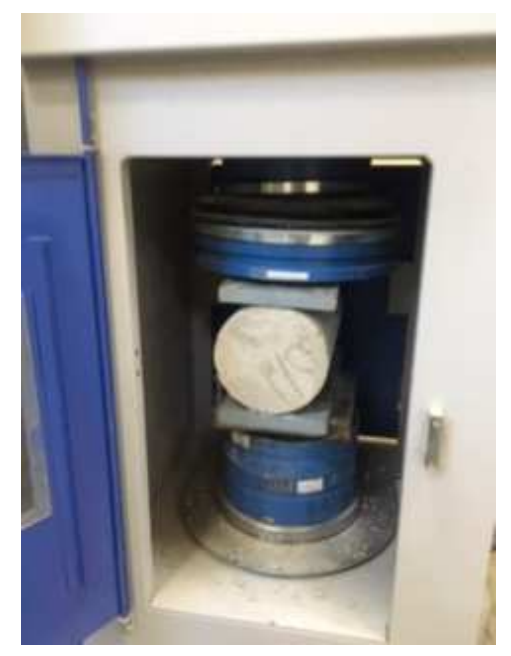

Figure (9), Splitting test of concrete cylinders 
STUDY OF BENTONITE USAGE IN ENVIRONMENTALLY FRIENDLY CONCRETE

Table (8), Splitting strength of the designed mixtures

\begin{tabular}{|c|c|}
\hline Mixture & $\begin{array}{c}\text { Split tensile strength } \\
\left(\mathbf{N} / \mathbf{m m}^{\mathbf{2}} \mathbf{)}\right.\end{array}$ \\
\hline Mix-B4 & 3.49 \\
\hline Mix-CR3 & 2.42 \\
\hline Mix-1 & 3.5 \\
\hline Mix-4 & 2.94 \\
\hline Mix-6 & 2.37 \\
\hline
\end{tabular}

\subsection{Abrasion test}

According to TS 2824 EN 1338, 2007, 2 cube specimens (Mix-1 and Mix-4) cured for 28 days in the size of $70 \times 70 \times 70 \mathrm{~mm}$ were subjected to the Bohme abrasion test. They were subjected to 16 cycles, each of which occurred 22 times. At the end of the experiment, reductions in the volume of the samples were determined. The test device used in the experiment is shown in figure (10). The results showed that by increasing the replacement of fine aggregates with crumb rubber the abrasion resistance increases. The abrasion of Mix-1 equals to $6.7 \mathrm{~cm}^{3}$ while the result of Mix-4 is 6.5 which is $5.7 \%$ increase of the abrasion resistance of concrete mixture.

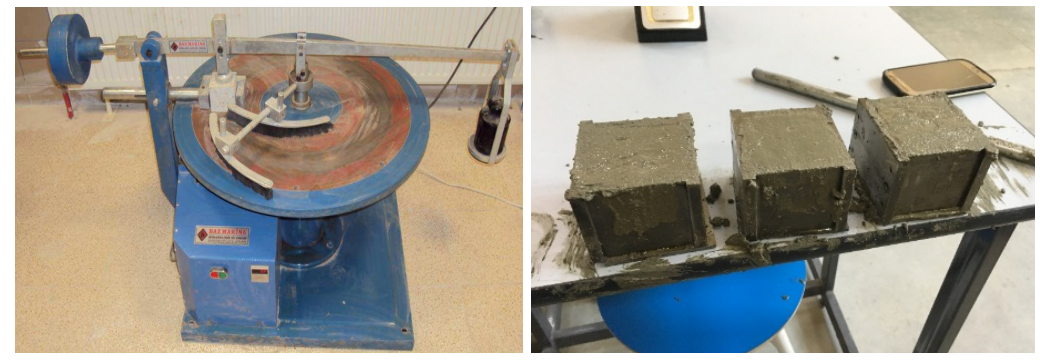

Figure(10), Abrasion test

\subsection{Durability test}

The durability of the concrete mixtures is tested, through sulfate attach and alkali attach by submerging specimens in solution containing $50 \mathrm{~g} / 1$ of $\mathrm{H}_{2} \mathrm{SO}_{4}$ and $\mathrm{NaOH}$ separately for 10 days after 28-days curing of the specimen as in figure (11). The compressive strength is determined for the tested specimen and the results indicate that the mixtures containing bentonite performed better than control mix. The cubes were tested, and the results have been recorded in table (9).
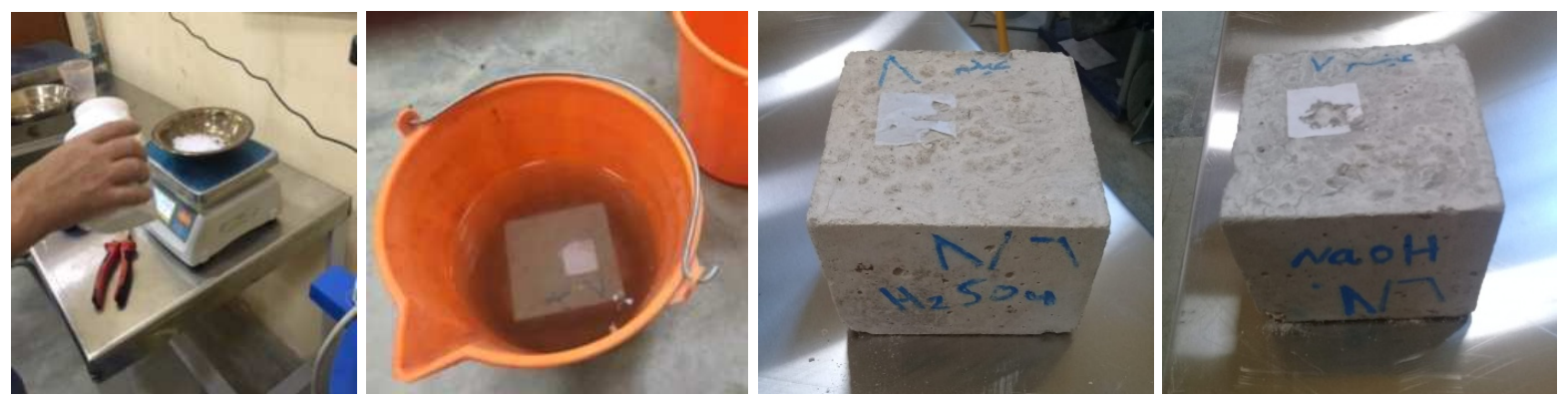

Figure (11) Durability test 
STUDY OF BENTONITE USAGE IN ENVIRONMENTALLY FRIENDLY CONCRETE

Table (9), Compressive strength and weight of the mixtures subjected by sulfate and alkali attach

\begin{tabular}{|c|c|c|c|c|c|}
\hline \multirow{2}{*}{ Mixture } & \multirow{2}{*}{$\begin{array}{c}\text { Weight } \\
\text { (Kg) }\end{array}$} & \multicolumn{2}{|c|}{$\begin{array}{l}\text { After submerging in solution of } \\
\mathrm{H}_{2} \mathrm{SO}_{4}\end{array}$} & \multicolumn{2}{|c|}{$\begin{array}{c}\text { After submerging in solution of } \\
\mathrm{NaOH}\end{array}$} \\
\hline & & $\begin{array}{c}\text { Compressive } \\
\text { strength }\left(\mathrm{N} / \mathrm{mm}^{2}\right)\end{array}$ & Weight (Kg) & $\begin{array}{c}\text { Compressive } \\
\text { strength }\left(\mathrm{N} / \mathrm{mm}^{2}\right)\end{array}$ & $\begin{array}{c}\text { Weight } \\
\text { (Kg) }\end{array}$ \\
\hline Mix-1 & 7.94 & 25.6 & 7.14 & 35 & 6.98 \\
\hline Mix-2 & 7.61 & 34.8 & 7.08 & 35 & 6.85 \\
\hline Mix-4 & 7.45 & 36.0 & 6.93 & 32 & 6.78 \\
\hline
\end{tabular}

\section{RESULTS}

The main objective is to conduct an environmentally friendly concrete by partially replacing cement with bentonite as a cementitious material and adding waste rubber crumb as a partial replacement with fine aggregates, also a cost saving concrete mixture by reducing the cement content that can achieve a compressive strength of 30MPa. The experimental investigation includes specimen with cement replacement by volume with bentonite by $(2 \%, 5 \%, 10 \%, 15 \%$, $20 \%)$. The compressive strength results of the different mixtures are shown in the figure (12) below at 7, and 28 days. The compressive strength result of Mix-B4 with $15 \%$ partial replacing the content of cement demonstrates the highest compressive strength value reached to $5 \%$ more than the reference mixture Mix-1 without additional bentonite. For Mix- B2 and Mix- B3 the compressive strength at 7 -days increased by $2 \%$ while Mix- B5 that demonstrate $20 \%$ replacement of cement, compressive strength decreased by 5\%. Although these mixes had comparable compressive strengths, they also had low workability as demonstrated by the respective low slump values in table (6). And this decrease in the slump value related to addition of Bentonite to the concrete mix that have a hygroscopic nature.

Also, the study includes sand replacement by volume with rubber crumb by $(5 \%, 20 \%, 25 \%$, $30 \%, 40 \%$ ), the results, as presented in figure (13), indicate a decrease in the compressive strength. Compressive strength reduction reached to $30 \%$ (Mix-CR2) by replacing rubber crumb by $20 \%$ and decreased by $90 \%$ with mixture Mix-CR3.

Mix-2 with $2 \%$ cement replacement and $5 \%$ crumb rubber, the tested compressive strength reached $21 \mathrm{MPa}$ at 7-days and $40 \mathrm{MPa}$ at 28-days which is the same as the control mixture Mix1. The tested results for Mix-3 mixture showed a compressive strength at 7-days $18 \mathrm{MPa}$ which represent a $15 \%$ reduction and a compressive strength at 28 -days $36 \mathrm{MPa}$ which represent a $11 \%$ reduction. Compressive strength at 28-days results for Mix-4 is found to be $33 \mathrm{MPa}$ with a reduction reached to $21 \%$ as shown in figure (14).

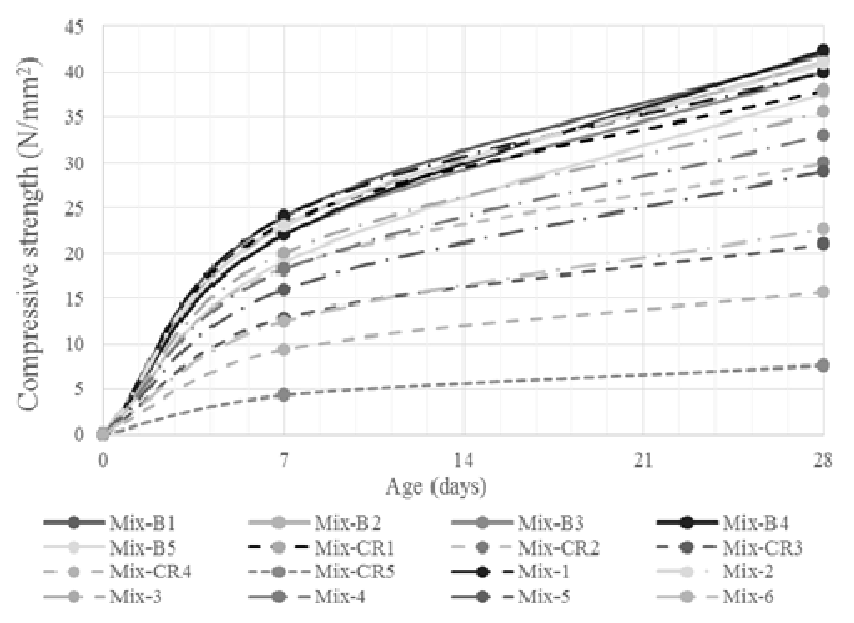

Figure (12), Compressive strength results of the different mixtures 


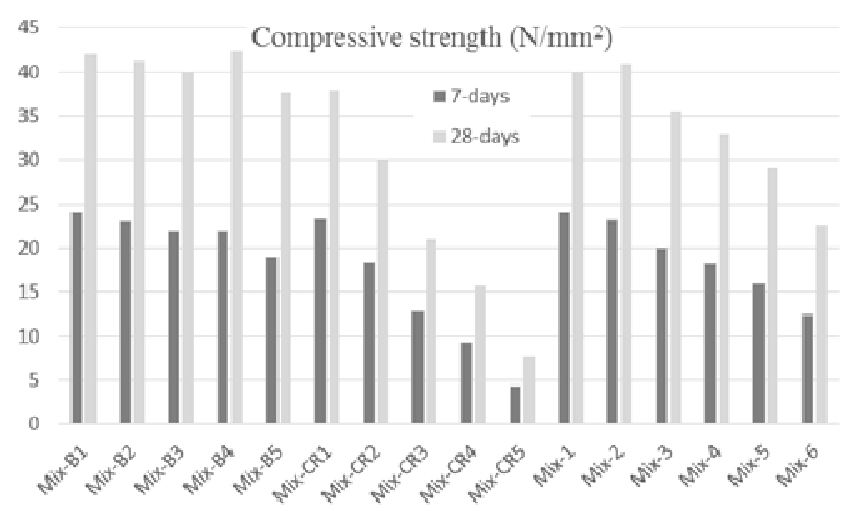

Figure (13), Compressive strength at 28-days

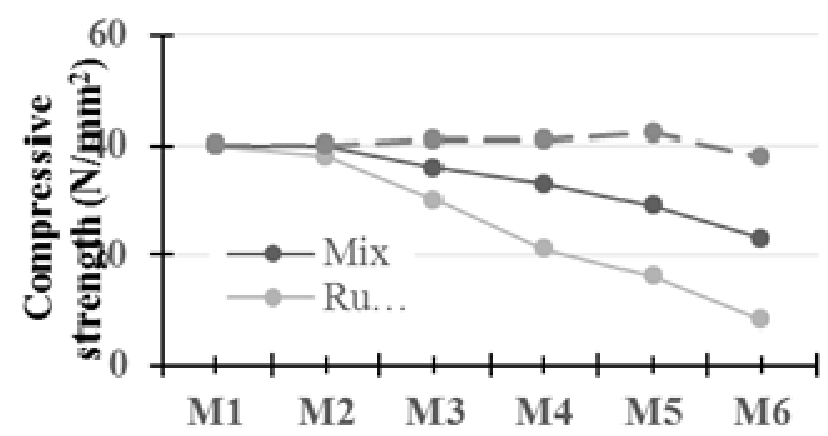

Figure (14), Compressive strength at 28-days for the three groups of mixtures

\section{CONCLUSION}

The main objective of this study is to investigate the potential use of bentonite and crumb rubber for producing environmentally friendly concrete with a cost saving. A laboratory investigation is to produce a concrete mixture with the lowest possible amount of cement which also met the strength requirement of $30 \mathrm{MPa}$ for various civil engineering applications. From the laboratory investigation including 16 mixtures in order to produce an optimal concrete mixture which achieves the required strength, it is recommended that Mix- 4 from this investigation be used. Mix- 4 with waste rubber tires $25 \%$ sand partial replacement and $10 \%$ cement partial replacement achieved a compressive strength of $30 \mathrm{MPa}$ at 28 days, better performance against acidic and alkalic attach and higher resistance to abrasion compared to conventional concrete.

\section{REFERENCES}

1. Murray, H. H. (2006). "Chapter 6 Bentonite Applications," Developments in Clay Science.

2. Alkaya, D. and Esener, B. (2011). "Usability of sand-bentonite-cement mixture in the construction of unpermeable layer," vol. 6, no. 21. pp. 4492-4503.

3. Targan, Ş., Olgun, A. S. İ. M., Erdogan, Y., \& Sevinc, V. (2002). Effects of supplementary cementing materials on the properties of cement and concrete. Cement and Concrete Research, 32(10), 1551-1558.

4. Mirza, R., Naseer, J. M. A. F., Rehman, A. N., Khan, and Ali, Q. (2009). "Pakistani bentonite in mortars and concrete as low-cost construction material," Applied Clay Science, vol. 45, no. 4. Elsevier B.V., pp. 220-226.

5. Khushnood, R. A., Rizwan, S. A., Memon, J. M., Tulliani, and Ferro,G. A.(2014). "Experimental Investigation on Use of Wheat Straw Ash and Bentonite in Self-Compacting Cementitious System,” Advances in Materials Science and Engineering, vol. 2014. 
6. Memon, S. A., Arsalan, R., Khan, S., \& Lo, T. Y. (2012). Utilization of Pakistani bentonite as partial replacement of cement in concrete. Construction and Building Materials, 30, 237-242.

7. Akbar, J., Alam, B., Ashraf, M., Afzal, S., Ahmad, A., and Shahzada, K. (2013). "Evaluating the Effect of Bentonite on Strength and Durability of High Performance Concrete," International Journal of Advanced Structures and Geotechnical Engineering, vol. 02, no. 01. pp. $1-5$.

8. Karthikeyan, M., Raja Ramachandran, P., Nandhini, A., and Vinodha, R. (2015). "Application on partial substitute of cement by bentonite in concrete," International Journal of ChemTech Research, vol. 8, no. 11. pp. 384-388.

9. Shabab, M. E., Shahzada, K., Gencturk, Ashraf, B., M. and Fahad, M. (2016). "Synergistic effect of fly ash and bentonite as partial replacement of cement in mass concrete," KSCE Journal of Civil Engineering, vol. 20, no. 5. pp. 1987-1995.

10. Reddy, G., Ranga Rao, V., and Achyutha Kumar Reddy, M. (2017). "Experimental investigation of strength parameters of cement and concrete by partial replacement of cement with Indian calcium bentonite,” Int. J. Civ. Eng. Technol., vol. 8, no. 1.

11. Divyana .R. (2015). "An Experimental Study on Concrete Using Bentonite and Steel Slag,"

12. Chandrakanth, M., Poorna, N. S., Rao, C., and Srinivasa Rao, K. (2016). "Experimental Studies on Concrete with Bentonite as Mineral Admixture".

13. Sreeniva, S. K, Praneeth, S. K. P, AchyuthA, K. R. M, and Ranga, R. V. (2017). "A Study on Durability of Concrete by Partial Replacement of Cement with Bentonite A Study on Durability of Concrete by Partial Replacement of," Int. Chem Tech Res., vol. 10, no. 6, pp. 898-904.

14. Ekaputri, J. J., et al.(2018). "Application of GGBFS and Bentonite to Auto-Healing Cracks of Cement Paste." Journal of Advanced Civil and Environmental Engineering 1.1 (2018): 38-48.

15. Tahiri, N., et al. (2018). "Nano-structural changes in $\mathrm{SiO}_{2}$ amended clay concrete under Alkali silica treatment".

16. Reddy, M. A. K., \& Rao, V. R. (2019, March). Utilization of Bentonite in Concrete: A. In International Conference on Advances in Civil Engineering (ICACE-2019) (Vol. 21, p. 23).

17. ASTM C192/192M-06. (2018). Standard practice for making and curing concrete test specimens in the laboratory, ASTM International, West Conshohocken, PA.

18. ASTM C1611 / C1611M-18. (2018). Standard Test Method for Slump Flow of SelfConsolidating Concrete, ASTM International, West Conshohocken, PA.

19. ASTM C192/192M-06. (2018). Standard practice for making and curing concrete test specimens in the laboratory, ASTM International, West Conshohocken, PA.

20. BS EN 12390-3. (2019). Standard Test Method for Compressive Strength, British Standards Institution, London.

21. ASTM C597-16. (2016). Standard Test Method for Pulse Velocity Through Concrete, ASTM International, West Conshohocken, PA.

22. ASTM C496 / C496M-17. (2017). Standard Test Method for Splitting Tensile Strength of Cylindrical Concrete Specimens, ASTM International, West Conshohocken, PA.

23. TS 2824 EN 1338. (2007).Standard Abrasion test, British Standards Institution, London. 